\title{
The Impact of Watching Movies on the Communication Skills of Nurs- ing Students: A Pilot Study from Turkey
}

\author{
Ilkay Keser* and Gülşah Acar \\ Department of Psychiatric Nursing, Akdeniz University, Turkey
}

*Corresponding author: Dr. Ilkay Keser, Assistant Professor, Department of Psychiatric Nursing, Faculty of Nursing, Akdeniz University, Antalya 07058, Turkey, Tel: +90506-5841675, E-mail: ikeser@akdeniz.edu.tr

\begin{abstract}
Communication skills can be improved in a variety of ways at any time of life. It is known in our country and in the world that watching films has a positive effect on individuals.

In addition to traditional verbal lectures teaching skills to be learned by students, watching movies is thought of as contributing to the acquisition of permanent knowledge. Therefore, this study was conducted to examine the effect of watching movies on nursing students' communication skills.

The research sample includes 20 student volunteers at Akdeniz University's Antalya School of Health who conformed to the criteria for inclusion. The research was carried out with one group as an experimental study with a pretest and a posttest. The data was obtained using a 7-question data collection form, a socio-demographic questionnaire and the Communication Skills Rating Scale. The Wilcoxon Matched-Pairs Signed-Ranks Test and the Mann Whitney $U$ test were used to evaluate the data.

It was determined that $70 \%$ of the participants are male, and $45 \%$ are twenty-years-old. Of the students, $70 \%$ are in their second year, $60 \%$ do not live with their family, but with friends, and $85 \%$ think their own communication skills are adequate. After the five week intervention, a statistically significant difference $(p<0.05)$ was found between the pretest and post-test scores of communication skills of the participants.

The research confirmed that the students' communication skills improved. Watching movies and discussing them significantly enhances the teaching and development of communication skills.
\end{abstract}

\section{Keywords}

Communication, Communication skills, Watching movies, Nursing students

\section{Introduction}

Communication is a process of mutual interaction that includes a two-way exchange of information, and the production and making sense of knowledge [1,2]. Since the nursing profession is based on human relations and interaction, the effectiveness of nursing care depends on an effective communication between nurses, patients and healthy people. To provide effective nursing care, nurses' ability to express themselves is as important as their observation and comprehension of the verbal and non-verbal expressions of patients and healthy people $[3,4]$.

The main objective of nursing education is to have students learn nursing practices and the professional philosophy of nursing. However, students also need to acquire specific skills such as building effective interpersonal communication and relationships, helping and consultation since nursing is a profession that serves people $[5,6]$. Undergraduate nursing students take courses focusing on communication. These courses enable them to increase their self-confidence and self-respect, improving them personally and professionally [7].

A review of the relevant literature indicates that skills training use a variety of methods including demonstrations, role playing, simulation and video screenings [8-13]. Students can gain permanent knowledge from traditional verbal lectures and by watching movies with relevant themes. Movies help students develop, not only professionally, but also socially. Movies cover a wide range of topics from science, visual arts and history to families in crisis, social solidarity, drug use and human rights, since these are all social phenomena that occur amongst the society [14]. This allows movies to be used in a wide range of contexts both as a primary and as a supplementary resource [15].

Some studies have proven that watching movies

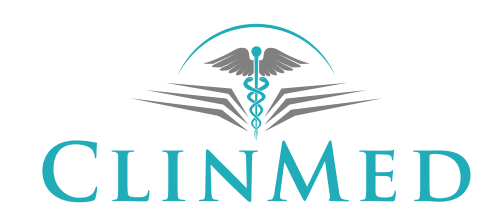

INTERNATIONAL LIBRARY
Citation: Keser I, Acar G (2017) The Impact of Watching Movies on the Communication Skills of Nursing Students: A Pilot Study from Turkey. Int Arch Nurs Health Care 3:078. doi.org/10.23937/2469-5823/1510078 Received: July 21, 2017: Accepted: September 08, 2017: Published: September 11, 2017

Copyright: (C) 2017 Keser I, et al. This is an open-access article distributed under the terms of the Creative Commons Attribution License, which permits unrestricted use, distribution, and reproduction in any medium, provided the original author and source are credited. 
has positive results for a variety of groups consisting of healthy and unhealthy people [16-24]. Powell, et al. [16] determined that the use of creative metaphors like watching movies was especially influential on teenagers. It was also found that when coping skills training was provided along with movie screenings, it was much more effective than training by itself [16]. A study conducted in our country found a significant change in the nationalism levels of a group of students after they watched a movie specifically chosen for them [20]. However, watching movies can be used not only with patients, but also with students since it can draw students' attention to certain skills and lead them to develop skills by becoming more aware [8-12]. Moreover, a study by Pur [19] found that alcoholics showed a significant increase in their levels of belief in their ability to give up drinking alcohol after collectively watching and discussing movies selected for them [19]. Learning effective communication skills in nursing education is accepted as necessary and inevitable. Thus, it may be argued that watching movies will help teach these skills. The learnable and teachable qualities of communication skills support these hypotheses.

In effective nursing care, observing and making sense of the verbal and non-verbal expressions of healthy and unhealthy people is just as important as the nurses' expressing themselves well $[3,4,11]$. For all these reasons, this study aims to analyze the effect of watching movies on the communication skills of nursing students.

\section{Materials and Methodology}

This study is an experimental study in single group pre-test/post-test design. The population of the study consisted of nursing students who educated in 20132014 academic year in Akdeniz University. Students participated in the conduct of the study voluntarily. They agreed to attend one movie screening and one discussion a week for five weeks. Students who failed to attend all the movie screenings and discussions were not included in the study. Finally, the 20 students who met the criteria for inclusion formed the sample of the study. The study was conducted with the approval of Akdeniz University's Medical School Ethics Committee.

\section{The study tool}

The data was obtained using a 7-question data collection form about watched film, a four questions including about age, gender, marital status and class, and the Communication Skills Rating Scale (CSRS) was used to assess their communication skills [12].

\section{The Communication Skills Rating Scale (CSRS)}

The scale was developed to understand the ways that individuals make use of their communication skills by Korkut in 1996. The original language of the scale is Turkish. The CSRS is a 5-point Likert type scale that consists of 25 statements. The scale was scored from "never" (1) to "always" (5). The scale does not include any inverted items. The highest score that can be taken from the scale is 100 , the lowest score is 0 . Higher scores indicate that individuals made positive use of their communication skills. The validity and reliability analysis of the CSRS were done, and the validity coefficient was found to be 0.58 . The reliability analysis was made using the test-retest method, and the reliability coefficient of the scale was found to be $0.76(p<0.001)$. The alpha value of the internal consistency coefficient was 0.80 ( $p<0.001$ ) [12]. The dependent variable of the research is The Communication Skills Rating Scale scores of the students.

\section{Implementation of the study}

This study had students watch certain movies with the themes of empathy, prejudice, anger, recklessness, coping and interpersonal relations which are among the main factors that have or aid communication. The movies selected for their themes and their inclusion of factors that either hinder or improve communication. For five weeks, students watched the movies. Criteria were set to identify the right films. Studies conducted in this regard have been examined. Many films have been watched by researchers to make sure that the films that constitute the basic steps of communication, such as listening, empathy, recognizing and expressing truth, are taken into consideration. We selected the movies in the list below (Table 1). After watching the movies, the students were encouraged to make 30-minute discussions that would make them think about the movie. Each session was guided by the same investigator, observed by the other investigator. At the end of each film, a discussion group was held with the students following the film. The data obtained at the end of each film in were first grouped independently by the investigators, then evaluated together by both investigators and final shape was given questions were asked before the debate to take students' thoughts into consideration because they would influence students' responses. The effect of watching the movies on the communication skills of the individuals was assessed by changing the pretest and post-test data. At the beginning of the work, pretest was performed before watching the first film, post-test was performed after watching all films. The discussions were made in framework of the questions below. In order to prevent data loss, the participants were asked to fill in a questionnaire that included the questions below during the first 10 minutes of each discussion; and the discussion was made for 20 minutes.

1. Can you describe a character in the movie?

2. What were the thoughts and feelings of this character?

3. What did this character consider their problem?

4. How did this character solve their problems? How did the character communicate? 
Table 1: Movies and student's expressions.

Week

1. Movie of the week

Movie/year

The Color of Paradise/1999

2. Movie of the week Forrest Gump/1994

3. Movie of the week The Merchant of Venice/2004

4. Movie of the week

The Story of Us/1999

5. Movie of the week

\section{Student's expressions after movies}

Students said that they were very impressed by this movie, especially by Mohammad. They also said that Aziz and the father were the other characters that impressed them. The discussion focused on Mohammad's ability to deal with difficulties in his life and his efforts to hold on to life, grandmother Aziz's efforts to keep the family together and changes in father's feelings. A general review of the movie indicated that students were able to recognize and comprehend concepts such as empathy, the importance of expressing one's feelings, coping skills, effective listening, providing help and not harming others.

Students said that they found the character Forrest Gump very impressing. They also said that the themes of the movie were Forrest Gump's point of view regarding the things that happen in his life, his ways of coping with them, consideration for handicapped people and getting rid of one's prejudices.

Students said that Antonio and Portia were the characters that impressed them most. The themes of the movie were identified as sacrifice, the importance of keeping one's promises in relationships, conflicts of interest in relationships, marginalizing different and distinct people, prejudices and the reflections of hate and anger on relationships.

Students talked about communication and family relationships. They discussed each character one by one, considering their roles in the family, their personality traits and patterns of communication. Students also discussed family dynamics, the characteristics that keep a family together, the importance of expressing emotions in the appropriate time and way, effective listening, caring for and empathizing with others.

Students said that James Stevens was the most impressing character for them. They discussed his shyness, his inability to express himself, the weak and fragile character hidden behind his strong and authoritarian image and the effects of these characteristics on his relationships. Students emphasized that one has to be able to express inner feelings and be flexible to build an effective communication in relationships.

- Taking the official permissions and ethics committee approval

2

- Determining the population and study sample

3

- Selection of the movies

- Implementing the pre-test procedure

5

- Making movie display sessions once a week for five weeks

6

- Implementing the post-test procedure

7

- Assessment of the data and writing period of the paper

Figure 1: Implementation plan and research schedule. 
5. What other solution could have been used by this character?

6. What is the relationship of this character with the other characters?

7. Who did you like the most? Who did you like the least?

8. Who did you identify with the most? Why?

Research implementation plan and research schedule is shown in Figure 1.

Since the number of participants was less than 30 , the data distribution was irregular. The non-parametrical tests were applied since the data distribution was not normal, and the scale used in the study depended on arrangement. Analyses were performed with IBM SPSS Statistics for Windows 22 (IBM Corp. Released 2013. Armonk, NY: IBM Corp.) software and two-tailed $P$ value less than 0.05 was considered statistically significant. The Wilcoxon Matched-Pairs Signed Rank Test, non-parametric statistical method used for dependent groups, was used to determine whether there was a difference between the pre-test and post-test results of the same group. The Mann Whitney U Test was applied to determine whether there was a difference between independent groups in terms of post-test results varied by age, gender, educational status and marital status.

\section{Findings}

Table 2 indicates that $45 \%$ of students were 20 years of age, $70 \%$ were males, $100 \%$ were single, $70 \%$ were second-year students. The Wilcoxon Test was used to determine whether there was a difference between the 20 students' scores before and after watching movies. Test Statistics: The total of sequence numbers of - and + signs that are rare in the signed new sequence number column. $\mathrm{T}_{\text {Calculation }}=41.5<\mathrm{T}_{\text {Table }}=20, \mathrm{p}<0.05$ change is statistically significant. As Table 3 shows, there is a

Table 2: Distribution of the students' socio-demographical data.

\begin{tabular}{|l|l|l|}
\hline Socio-demographical data & \multicolumn{2}{l|}{} \\
\hline Age & \multicolumn{2}{l|}{} \\
\hline 20 & 9 & 45.0 \\
\hline 21 & 3 & 15.0 \\
\hline 22 & 4 & 20.0 \\
\hline 23 & 2 & 10.0 \\
\hline 25 & 1 & 5.0 \\
\hline 27 & 1 & 5.0 \\
\hline Gender & & \\
\hline Female & 6 & 30.0 \\
\hline Male & 14 & 70.0 \\
\hline Marital status & & \\
\hline Married & 0 & 0 \\
\hline Single & 20 & 100.0 \\
\hline Class & & \\
\hline First-year & 1 & 5.0 \\
\hline Second-year & 14 & 70.0 \\
\hline Third-year & 3 & 15.0 \\
\hline Fourth-year & 2 & 10.0 \\
\hline Total & 20 & 100.0 \\
\hline
\end{tabular}

Table 3: The Wilcoxon test results for participants' CSRS scores.

\begin{tabular}{|c|c|c|c|c|c|c|c|}
\hline $\begin{array}{l}\text { Number of } \\
\text { participant }\end{array}$ & Pre-test & Post-test & $\begin{array}{l}\text { Marked } \\
\text { difference }\end{array}$ & $\begin{array}{l}\text { Unsigned } \\
\text { difference }\end{array}$ & Rank & $\mathrm{ER}^{\star}$ & $\mathrm{MR}^{* *}$ \\
\hline 1 & 34.00 & 39.00 & 5.00 & 5 & 4 & 5 & 5 \\
\hline 2 & 46.00 & 56.00 & 10.00 & 10 & 10 & 10.5 & 10.5 \\
\hline 3 & 37.00 & 49.00 & 12.00 & 12 & 14 & 15 & 15 \\
\hline 4 & 43.00 & 54.00 & 11.00 & 11 & 12 & 12.5 & 12.5 \\
\hline 5 & 36.00 & 59.00 & 23.00 & 23 & 19 & 19 & 19 \\
\hline 6 & 70.00 & 60.00 & -10.00 & 10 & 11 & 10.5 & -10.5 \\
\hline 7 & 43.00 & 38.00 & -5.00 & 5 & 5 & 5 & -5 \\
\hline 8 & 32.00 & 41.00 & 9.00 & 9 & 9 & 9 & 9 \\
\hline 9 & 33.00 & 30.00 & -3.00 & 3 & 3 & 3 & -3 \\
\hline 10 & 42.00 & 49.00 & 7.00 & 7 & 7 & 7 & 7 \\
\hline 11 & 47.00 & 45.00 & -2.00 & 2 & 2 & 2 & -2 \\
\hline 12 & 43.00 & 42.00 & -1.00 & 1 & 1 & 1 & -1 \\
\hline 13 & 47.00 & 58.00 & 11.00 & 11 & 13 & 12.5 & 12.5 \\
\hline 14 & 39.00 & 56.00 & 17.00 & 17 & 17 & 17 & 17 \\
\hline 15 & 53.00 & 48.00 & -5.00 & 5 & 6 & 5 & -5 \\
\hline 16 & 35.00 & 47.00 & 12.00 & 12 & 15 & 15 & 12 \\
\hline 17 & 50.00 & 58.00 & 8.00 & 8 & 8 & 8 & 8 \\
\hline 18 & 52.00 & 42.00 & -12.00 & 12 & 16 & 15 & -15 \\
\hline 19 & 58.00 & 80.00 & 22.00 & 22 & 18 & 18 & 18 \\
\hline 20 & 32.00 & 61.00 & 29.00 & 29 & 20 & 20 & 20 \\
\hline
\end{tabular}

*ER: Edited Rank; **MR: Marked Rank. 
statistically significant difference between pre-test and post-test scores of the participants. The result of the calculation is smaller than 52 , which is the value of the table; this shows that there is a difference.

Along with these statistical data, the findings acquired through the after-movie evaluations support each other. The author observed that week after week the students increased their levels of noticing the factors which affected communication and participation in the discussions. Here are the findings generated by the after-movie discussions:

The analyses indicated that the students focused on the themes shown in Table 1. Regarding the communication between the characters in the movies, the author discussed correct and incorrect communication patterns with the group based on examples. During these discussions, students stressed that the concepts of trust, respect, sacrifice, effective listening and assigning value were important in communication with other individuals in daily life. The students said that coping skills affected individuals' perspectives on events and, accordingly, their communication skills.

They described anger management, one of the factors that hinders communication, as an important communication problem. They also said that not keeping one's promises, hatred, and rage all had negative effects on relationships. They said that empathizing was understanding and feeling another person's emotions correctly and telling this to him or her. They also said that an individual with strong empathizing skills will be much braver.

During discussions, students emphasized that non-verbal expressions were as important as verbal expression. They talked about the communication examples they noticed in the films, and said that good use of body language, making eye contact, touching and tone of voice were important for communication. The students also said that shyness, insufficiency in expressing oneself and a weak and fragile personality had a negative effect on interpersonal relationships. They stressed that being able to express oneself and being flexible were necessary to build effective communication in relationships. Moreover, the students said that people marginalize others who are not like them or are from different segments of society and have prejudices about them.

Based on these evaluations, the students stressed that being informed about these basic concepts was important to be able to build effective relationships between patients and nurses. Students said that nurses should leave their prejudices aside while working with individuals from different cultures to be able to build healthy relationships. They also said that cultural characteristics and living experiences influenced the development of prejudices. Students also emphasized that valuing people with different characteristics was important, and prejudices in the communication with patients would have a negative influence on health care. They said that if anger cannot be managed, it can harm both patients and nurses. Thus, they said that it was important for nurses to get to know themselves and be aware of ways to control their anger. Students also said that effective listening, expressing feelings in the right place and the right time and valuing others were important to be able to use empathy in relationships between patients and nurses. They said it was important in communication that nurses know their emotions well. They said that if nurses know themselves well, it will be easier for them to control their behavior and express themselves. Students also emphasized that nurses should be brave in their relationships with both patients and other health professionals.

\section{Discussion}

The results of our study showed that watching movies is effective in teaching communication skills. The findings revealed that there was a significant difference between participants' pre-test and post-test scores on the CSRS. Thus the researchers' intervention contributed to the positive development of participants' communication skills. Past studies have also shown that watching movies triggers positive changes in individuals related to the aim of the observation $[8,12,16,20,24,25]$. These findings are in accordance with the findings of this study.

According to the study results, students thought that both verbal and non-verbal expressions were important in communication, and that they both influence interpersonal relationships. In their study, Klemenc-Ketis and Kersnik [26] found that communication is an essential component of nurses' relationship with patients according to students. They suggested that non-verbal communication was specifically necessary to be able to build successful communication with patients. Accordingly, they said that certain skills including effective listening skills, making eye contact, touching, and noticing patients' non-verbal expressions and responding to them were important [26].

Using verbal and non-verbal communication skills, nurses can effectively express that they care for their patients and that they listen attentively to their concerns. The importance of proper communication being a part of professional behaviour has been recognised also in other teaching programs that dealt with cinemeducation, directly $[27,28]$ or indirectly $[29,30]$.

Past studies also assert that students review their own behavior models while watching movies, and change their incorrect behaviors $[23,25,26,31]$. This study also found that students increased their participation into discussions as well as their recognition levels of the factors that influenced communication. They also make a distinction of correct and incorrect behaviors. This finding is consistent with the relevant literature. 
The relevant studies suggest that watching movies and plays helps convey sociocultural and anthropological information and facilitates understanding human life [32-34]. In this study, students said that nurses should leave their prejudices behind when working with people from different cultures to be able to build healthy relationships with them and that cultural characteristics and life experiences affect the development of prejudices.

Relevant studies in the literature stress that the communication between the patient and the nurse is a very important part of a high quality nursing care $[3,4,11,13,35,36]$. In their study, Suikkala and Leino-Kilpi [7] state that undergraduate nursing students are provided courses in communication to give them more confidence and self-respect, which contributes to their professional development [7]. The movies and themes included in this study were discussed in groups and supported with a variety of examples aimed at improving nursing students' communication skills. The participants stated that this intervention helped them to improve their communication skills and gain different perspectives. In the discussions, the participants identified specific themes and used these themes to emphasize that good communication between patients and nurses is very important. These outcomes are in accordance with the findings in relevant literature.

The controlled environment of movies successfully enables students to explore their values, beliefs, and attitudes towards features of communication skills without feeling that their personal integrity had been threatened. Interactive teaching methods could become an indispensible aid in teaching communication skills to new generations.

\section{Conclusion and Implications}

This study has several limitations. The first one is a small sample, which limits us to generalise conclusions to all students. Nevertheless, this was a small study which allowed us to explore students' feelings, attitudes and values and as such we can regard it as a representative one for further planning of the curriculum. As stated before, the study outcomes indicate that the participants made positive changes in their communication skills despite certain influential factors, such as the study's use of One Group Pretest-Post-test Design, the lack of a control group, the limited duration of the intervention and no follow-up assessments. The study outcomes should be evaluated with these factors in mind. Another limitation is with this study, the authors did not explore how well the students' knowledge, gained by this elective course, will translate into their later professional life. This should also be assessed by further studies.

Nursing students recognized the fact that they will be working with many different kinds of individuals. This led them to understand that these concepts play a major role in the communication and relationships between patients and nurses. It is estimated that study aids (e.g., watching movies) along with theoretical lessons help nursing students to enhance their communication skills permanently.

Education on nursing is an intense and tiring process. Different educational methods should be used to make this process as effective as possible. Interactive teaching methods could become an indispensible aid in teaching communication skills to new generations. This research shows that watching movies with students is beneficial. Thus, this method should be used in the nursing curriculum. Watching movies with students can also be effective in learning other professional skills that are peculiar to the occupation of nursing. Further studies about the impact of movies should be done on much larger samples of students.

\section{References}

1. Cüceloğlu D (1998) Yeniden İnsan İnsana, Remzi Kitabevi, Istanbul.

2. Dökmen Ü (1998) İletişim Çatışmaları ve Empati, 7. Basım, Sistem Yayıncılık, İstanbul.

3. Terakye G (1995) Hasta Hemşire İlişkileri, Aydoğdu Ofset, Ankara.

4. Babadağlı B, Erim ES, Erdoğan S (2006) Hekimlerin ve hemşirelerin hastayla iletişim becerilerinin değerlendirilmesi. Fırat Sağlık Hizmetleri Dergisi 3: 54-69.

5. Sanford PG (2010) Simulation in nursing education: A review of the research. The Qualitative Report 15: 1006-1011.

6. Arifoğlu B, Razı GS (2011) Birinci sınıf hemşirelik öğrencilerinin empati ve iletişim becerileriyle iletişim yönetimi dersi akademik başarı puanı arasındaki ilişki. Dokuz Eylül Üniversitesi Hemşirelik Yüksekokulu Elektronik Dergisi 4: 7-11.

7. Suikkala A, Leino-Kilpi $H$ (2001) Nursing student-patient relationship: A review of the literature from 1984 to 1998 . J Adv Nurs 33: 42-50.

8. Wall BM, Rossen EK (2004) Media as a teaching tool in psychiatric nursing education. Nurse Educ 29: 36-40.

9. Mete S, Uysal N (2009) Hemşirelik mesleksel beceri eğitiminde bir model uygulaması. Dokuz Eylül Üniversitesi Hemşirelik Yüksekokulu Elektronik Dergisi 2: 115-123.

10. Mıdık Ö, Kartal M (2010) Simülasyona dayalı tıp eğitimi. Marmara Medical Journal 23: 389-399.

11. Mert H, Sezgin D (2011) Geleneksel ve probleme dayalı öğrenim modeliyle öğrenim gören hemşirelik öğrencilerinin empatik beceri düzeylerinin incelenmesi. Anadolu Hemşirelik ve Sağlık Bilimleri Dergisi 14: 9-13.

12. Korkut $F$ (1996) İletişim Becerilerini Değerlendirme Ölçeği'nin geliştirilmesi: Güvenirlik ve geçerlik çalışmaları. Psikolojik Danışma ve Rehberlik Dergisi 2: 18-23.

13. Gençöz F (2007) Psinema. Sinemada Psikolojik Bozukluklar ve Sinematerapi. Hekimler Yayın Birliği Yayınları, Ankara.

14. Hathaway C (2013) Using film, television and other media to teach management and leadership concepts. Nurse Educ 38: 239-240.

15. Birkök MC (2008) Bir toplumsallaştırma aracı olarak eğitimde alternatif medya kullanımı: Sinema filmleri. Uluslararası İnsan Bilimleri Dergisi 5: 1-12. 
16. Powell ML, Newgent RA, Lee SM (2006) Group cinematherapy: Using metaphor to enhance adolescent self-esteem. The Arts in Psychotherapy 33: 247-253.

17. Frieden J, Elliott D (2007) Teach with movies: Using the storytelling power of movies to motivate students. Teacher Librarian 34: 61.

18. Lane C, Rollnick S (2007) The use of simulated patients and role play in communication skills training: A review of the literature to August 2005. Patient Educ Couns 67: 13-20.

19. Pur IG (2009) Alkol bağımlıları için sinematerapi (Yüksek Lisans Tezi). Orta Doğu Teknik Üniversitesi.

20. Aka BT, Gençöz F (2010) Sinematerapinin mükemmeliyetçilik ve mükemmeliyetçilikle ilgili şemalar üzerindeki etkisi. Türk Psikoloji Dergisi 25: 69-77.

21. Edmonds $M$ (2013) The use of the film in teaching qualitative inquiry to graduate nursing students. J Nurs Educ 52: 179-180.

22. Sarı OT (2014) Film izleme, empati ve zihin kuramı: Asperger sendromlu bireyle yapılan vaka çalışması. Eğitim ve Oğretim Araştırmaları Dergisi. Journal of Research in Education and Teaching 3: 322-332.

23. Sedghi S, Rangbar F, Mohtashami J, Alavi MH (2014) The use of simulation in therapeutic communication skills achievement in undergraduate nursing students in psychiatric wards of Shahid Beheshti University of Medical Sciences. International Journal in IT and Engineering 2: 15-26.

24. Pace CJ, Lim FA (2014) The american nurse: Healing america a film companion guide for academic and clinical nursing. American Nurses Foundation.

25. Oh J, Kang J, De Gagne JC (2012) Learning concepts of cinenurducation: An integrative review. Nurse Educ Today 32: 914-919.
26. Klemenc-Ketis Z, Kersnik J (2011) Using movies to teach professionalism to medical students. BMC Med Educ 11: 60.

27. Winter RO, Birnberg BA (2006) Teaching professionalism artfully. Fam Med 38: 169-171.

28. Alexander M, Hall MN, Pettice YJ (1994) Cinemeducation: An innovative approach to teaching psychosocial medical care. Fam Med 26: 430-433.

29. Pavlov A, Dahlquist GE (2010) Teaching communication and professionalism using a popular medical drama. Fam Med 42: 25-27.

30. Belling C (2006) The "bad news scene" as clinical drama part 2: Viewing scenes. Fam Med 38: 474-475.

31. Young HK, Eun K, Sook LE (2012) Effects of simulation-based education on communication skill and clinical competence in maternity nursing practicum. Korean $\mathrm{J}$ Women Health Nurs 18: 312-320.

32. Salinsky J (2005) Half a day at the movies: Film studies in the VTS course. Br J Gen Pract 55: 806-809.

33. Marcus ER (1999) Empathy, humanism, and the professionalism of medical education. Acad Med 74: 1211-1215.

34. Quadrelli S, Colt HG, Semeniuk G (2009) Appreciation of the aesthetic: A new dimension for a medicine and movies program. Fam Med 41: 316-318.

35. Thomas CM, Bertram E, Johnson D (2009) The SBAR communication technique: Teaching nursing students professional communication skills. Nurse Educ 34: 176-180.

36. Enlow M, Shanks L, Guhde J, Perkins M (2010) Incorporating interprofessional communication skills (ISBARR) into an undergraduate nursing curriculum. Nurse Educ 35: 176-180. 